\title{
A New ent-Clerodane Diterpene from Hymenaea courbaril var. altissima
}

\author{
Raquel T. Nogueira ${ }^{a}$, Rosana A. Giacomini ${ }^{a}$, George J. Shepherd ${ }^{b}$ and Paulo M. Imamura*a \\ ${ }^{a}$ Instituto de Química, Universidade Estadual de Campinas, CP 6154, 13083-970, Campinas - SP, Brazil \\ ${ }^{b}$ Instituto de Biologia, Universidade Estadual de Campinas, CP 6109, 13083-970, Campinas - SP, Brazil
}

Da casca do tronco de Hymenaea courbaril var. altissima (Ducke) foi isolado um novo entclerodano na forma de éster metílico, após esterificação com diazometano, o (-)-(5R,8S,9S,10R)clerod-3-en-15-oato de metila. Foram isolados também dois ent-labdanos conhecidos: o (-)-copalato de metila e (-)-eperuato de metila. Do extrato AcOEt do epicarpo foi isolado, após esterificação com diazometano, o (-)-zanzibarato de metila. As estruturas dos compostos foram elucidadas com base na análise de dados espectroscópicos.

\begin{abstract}
A new ent-clerodane and two known ent-labdanes were isolated from the barks of Hymenaea courbaril var. altissima (Ducke). The new diterpene was identified, after esterification with diazomethane, as methyl (-)-(5R,8S,9S,10R)-clerod-3-en-15-oate and known diterpenes were identified as methyl (-)-copalate and methyl (-)-eperuate. From the EtOAc extract of seed pods a known methyl (-)-zanzibarate was isolated. The structures of isolated compounds were elucidated based on spectroscopic studies.
\end{abstract}

Keywords: Hymenaea courbaril var. altissima, ent-clerodane, ent-labdane

\section{Introduction}

Hymenaea is a genus widely distributed from Central to South America and is known popularly as "jatobá", "jataí" or "jutaí". The wood is used for woodwork and the resin extract is locally used as a remedy for many purposes. ${ }^{2}$ The chemical composition of the resin obtained from some species of Hymenaea is already known in the literature $^{3}$ and recently we reported the isolation of two new ent-clerodane derivatives from the seed pods resin of H. courbaril var. stilbocarpa. ${ }^{4}$ We now describe the isolation of two known diterpenes $(\mathbf{1}, \mathbf{2})$ and a novel entclerodane (3) from the ethyl acetate extract of $H$. courbaril var. altissima (Ducke) barks, which grows mainly in a subtropical forest on the Atlantic Coast, ${ }^{5}$ and the isolation of a known diterpene (9) from the ethyl acetate extract of its seed pods. Another five compounds (4-8) were also identified by GC/MS analyses.

\section{Results and Discussion}

The ethyl acetate extract of $H$. courbaril var. altissima barks was esterified with diazomethane and submitted to a

* e-mail: imam@iqm.unicamp.br combination of column chromatography (silica gel) and preparative TLC on $\mathrm{SiO}_{2} / \mathrm{AgNO}_{3}(5 \%$, w/w), to afford a new diterpene, methyl (-)-(5R,8S,9S,10R)-clerod-3-en-15-oate (3), along with the known methyl (-)-copalate (1) ${ }^{6}$ and methyl (-)-eperuate (2). ${ }^{7}$ Through GC/MS analysis of the methylated extract, besides compounds 1-3, five known diterpenes were also identified by their retention indices and by co-injection with authentic samples as: methyl isoozate (4), ${ }^{4}$ methyl ozate (5), ${ }^{4}$ methyl kovalenate (6), ${ }^{4}$ methyl $\left(5 \mathrm{~S}^{*}, 8 \mathrm{~S}^{*}, 9 \mathrm{~S}^{*}, 10 \mathrm{R}^{*}\right)$ clero-3,13-dien-15-oate $(7)^{4}$ and methyl ( $\left.5 \mathrm{R}^{*}, 8 \mathrm{~S}^{*}, 9 \mathrm{~S}^{*}, 10 \mathrm{R}^{*}\right)$ clero-3,13-dien-15-oate (8). ${ }^{4}$

The ethyl acetate extract of seed pods of $H$. courbaril var. altissima was esterified with diazomethane and submitted to a combination of column chromatography (silica gel), preparative TLC on $\mathrm{SiO}_{2} / \operatorname{AgNO}_{3}(5 \%$, w/w) and RP-HPLC to give a known methyl (-)-zanzibarate (9). ${ }^{8}$ Through GC/MS analysis of the methylated extract, three known diterpenes: methyl isoozate (4), methyl ozate (5) and methyl kovalenate (6) were also identified by retention indices and by co-injection with authentic samples. ${ }^{4}$

Methyl (-)-(5R,8S,9S,10R)-clerod-3-en-15-oate (3) was obtained as colorless oil, $[\alpha]_{\mathrm{D}}^{20}-54.0\left(c 0.6, \mathrm{CHCl}_{3}\right)$ and HRMS data $(m / z$ 320.27156) suggested the molecular formula $\mathrm{C}_{21} \mathrm{H}_{36} \mathrm{O}_{2}$. The ${ }^{1} \mathrm{H}$ NMR spectrum of 3 showed two signals at $\delta 0.89(s, 3 \mathrm{H})$ and $1.05(s, 3 \mathrm{H})$, corresponding to 

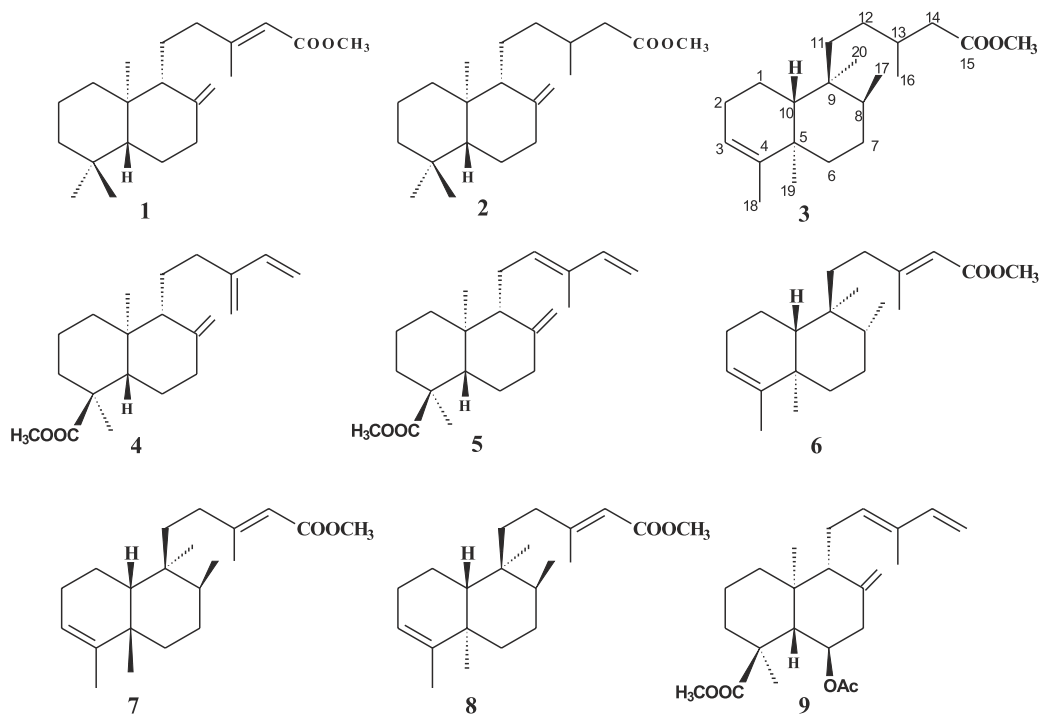

the methyl groups attached to a quaternary carbon and two signals at $\delta 0.90(\mathrm{~d}, J 7.0 \mathrm{~Hz}, 3 \mathrm{H})$ and $0.96(\mathrm{~d}, J 6.6 \mathrm{~Hz}$, $3 \mathrm{H})$, corresponding to the methyl groups attached to a methine carbon. Signal for an additional methyl group, attached to a sp ${ }^{2}$ carbon at $\delta 1.59(\mathrm{brd}, J 1.5 \mathrm{~Hz}, 3 \mathrm{H})$ coupled to a vinylic hydrogen at $\delta 5.20(\mathrm{brs}, 1 \mathrm{H})$, was observed.

The full ${ }^{1} \mathrm{H}$ and ${ }^{13} \mathrm{C}$ NMR signals assignment was based on homonuclear and heteronuclear 2D experiments (COSY90, HSQC) and by comparison with the ${ }^{13} \mathrm{C}$ NMR spectral data of the previously isolated compound $\mathbf{8},{ }^{4}$ which showed a good agreement for the chemical shifts of carbons belonging to the decalin moiety.

The ${ }^{1} \mathrm{H}$ NMR spectrum also revealed signals for methylene hydrogens $(\delta 2.13$, dd, $J 9.0$ and $4.4 \mathrm{~Hz} ; 2.35$ dd, $J 9.0$ and $4.4 \mathrm{~Hz}$ ) adjacent to a carbomethoxyl group and cross peaks in the COSY spectrum showing their coupling to a methinic hydrogen at $\delta 1.88(\mathrm{~m})$. This hydrogen was, in turn, connected to the methyl group at $\delta$ 0.96 and methylene hydrogens at $\delta 1.33(\mathrm{~m})$. The ${ }^{13} \mathrm{C}$ NMR data connectivity analyses and comparison of ${ }^{13} \mathrm{C}$ NMR data of the side chain of $\mathbf{3}$ with those of $\mathbf{2}$ were in good agreement. The chemical shift of carbon C-19, that appeared at $\delta 20.6$, confirms the trans relationship for A/B ring. ${ }^{4}$ The assignments for all signals were fully confirmed by HSQC and HMBC experiments.

\section{Experimental}

\section{General}

${ }^{1} \mathrm{H}$ - and ${ }^{13} \mathrm{C}$-NMR spectra were recorded in $\mathrm{CDCl}_{3}$ solution at $300 \mathrm{MHz}$ and $75 \mathrm{MHz}$, respectively, with a Bruker AC 300/P spectrometer (internal standard TMS). IR spectra of neat samples were obtained on a Perkin-Elmer
1600 series FTIR. Mass spectra of purified compounds were obtained at $70 \mathrm{eV}$ on an Hewlett-Packard 5990/5970 system equipped with a J\&W Scientific DB-5 fused silica capillary column $(30 \mathrm{~m} \times 0.25 \mathrm{~mm} \times 0.25 \mathrm{~mm})$. Highresolution mass spectra (HRMS) were performed with a VG 7070E spectrometer by electron impact with beam energy of $70 \mathrm{eV}$. Optical rotations were measured with a Carl Zeiss photoelectric polarimeter.

\section{Isolation}

The seed pods and barks of Hymenaea courbaril var. altissima (Ducke) were collected in March 1994 at Fazenda Santa Elisa (IAC- Campinas), São Paulo State, Brazil. A voucher specimen was deposited in the Herbarium of IBUEC (\# no. GS 01/03). Dry barks ( $360 \mathrm{~g}$ ) were powdered and extracted with EtOAc (3L) for 5 days at room temperature. After filtration and evaporation of solvent at reduced pressure a crude extract $(34 \mathrm{~g})$ was obtained as an oily resin. A sample of resin $(789 \mathrm{mg})$ was esterified with diazomethane and submitted successively for purification using silica gel column chromatography $\left(\mathrm{CHCl}_{3}: \mathrm{MeOH}\right.$ $1 \%$ to $5 \%$, v/v), prep TLC on $\mathrm{SiO}_{2} / \mathrm{AgNO}_{3}(5 \%$, w/w) eluting with a mixture of different solvents and polarity (petroleum ether/EtOAc/ $\mathrm{CH}_{2} \mathrm{Cl}_{2}$ ) to yield (-)-methyl copalate (1) $\left\{11 \mathrm{mg},[\alpha]_{\mathrm{D}}^{20}-19.0 \mathrm{CHCl}_{3}, c 0.7 ;\right.$ lit., $\left.{ }^{6}[\alpha]_{\mathrm{D}}^{20}-12.9\right\}$, methyl eperuate (2) $\left\{15 \mathrm{mg},[\alpha]_{\mathrm{D}}^{20}-24.0 \mathrm{CHCl}_{3}, c 1.1 ;\right.$ lit. ${ }^{7},[\alpha]_{\mathrm{D}}^{20}$ $-26.0\}$ and methyl (-)-(5R,8R,9R,10S) clerod-3-en-15-oate (3) $\left\{12 \mathrm{mg},[\alpha]_{\mathrm{D}}^{20}-54.0 \mathrm{CHCl}_{3}, c 0.6\right\}$. GC/MS analysis of the barks methylated extract indicated: methyl isoozate (4) (3.7\%), methyl ozate (5) (3.9\%), methyl kovalenate (6) (3.2\%), methyl $\left(5 \mathrm{~S}^{*}, 8 \mathrm{~S}^{*}, 9 \mathrm{~S}^{*}, 10 \mathrm{R}^{*}\right)$-cleroda-3,13-dien-15oate (7) $(2.3 \%)$ and methyl $\left(5 \mathrm{R}^{*}, 8 \mathrm{~S}^{*}, 9 \mathrm{~S}^{*}, 10 \mathrm{R}^{*}\right)$-cleroda3,13-dien-15-oate (8) (0.8\%). 
Table 1. ${ }^{1} \mathrm{H}$ and ${ }^{13} \mathrm{C}$ NMR spectral data of $3(300 \mathrm{MHz}, 75 \mathrm{MHz})$ and ${ }^{13} \mathrm{C}$ NMR spectral data of 2 and 8 in $\mathrm{CDCl}_{3}(75 \mathrm{MHz})$

\begin{tabular}{|c|c|c|c|c|}
\hline \multirow[b]{2}{*}{ Position } & \multicolumn{2}{|c|}{3} & \multirow{2}{*}{$\begin{array}{c}\mathbf{2} \\
\delta_{\mathrm{C}}(\mathrm{ppm})\end{array}$} & \multirow{2}{*}{$\begin{array}{c}\mathbf{8}^{4} \\
\delta_{\mathrm{C}}(\mathrm{ppm})\end{array}$} \\
\hline & $\delta_{\mathrm{C}}(\mathrm{ppm})$ & $\delta_{\mathrm{H}}(\mathrm{ppm})$ & & \\
\hline 1 & 17.8 & $1.40 \mathrm{~m}$ & 39.1 & 17.9 \\
\hline 2 & 26.8 & $1.97 \mathrm{~m}, 2.08 \mathrm{~m}$ & 19.4 & 26.8 \\
\hline 3 & 120.2 & $5.20 \mathrm{brs}$ & 42.2 & 120.2 \\
\hline 4 & 144.6 & & 33.6 & 144.4 \\
\hline 5 & 37.4 & & 55.6 & 37.6 \\
\hline 6 & 30.2 & $1.45 \mathrm{~m}$ & 24.5 & 30.1 \\
\hline 7 & 25.6 & $1.25 \mathrm{~m}$ & 38.4 & 25.5 \\
\hline 8 & 35.1 & $1.60 \mathrm{~m}$ & 148.8 & 35.1 \\
\hline 9 & 38.3 & & 56.9 & 38.8 \\
\hline 10 & 45.2 & $1.45 \mathrm{~m}$ & 39.7 & 45.1 \\
\hline 11 & 37.4 & $1.33 \mathrm{~m}$ & 20.8 & 37.5 \\
\hline 12 & 36.6 & $\begin{array}{c}1.05 \mathrm{dt}(J 9.2 \text { and } 3.5 \mathrm{~Hz}) \\
1.40 \mathrm{~m}\end{array}$ & 35.8 & 34.8 \\
\hline 13 & 31.5 & $1.88 \mathrm{~m}$ & 30.9 & 164.0 \\
\hline 14 & 41.7 & $\begin{array}{l}2.13 \mathrm{dd}(J 9.0 \text { and } 4.4 \mathrm{~Hz}) \\
2.35 \mathrm{dd}(J 9.0 \text { and } 4.4 \mathrm{~Hz})\end{array}$ & 41.9 & 114.3 \\
\hline 15 & 173.8 & & 173.8 & 170.7 \\
\hline 16 & 20.0 & $0.96 \mathrm{~d}(J 6.6 \mathrm{~Hz})$ & 19.6 & 19.5 \\
\hline 17 & 14.8 & $0.90 \mathrm{~d}(J 7.0 \mathrm{~Hz})$ & 106.2 & 14.8 \\
\hline 18 & 18.0 & $1.59 \mathrm{bd}(J 1.5 \mathrm{~Hz})$ & 33.6 & 18.0 \\
\hline 19 & 20.6 & $1.05 \mathrm{~s}$ & 21.7 & 20.6 \\
\hline 20 & 20.4 & $0.89 \mathrm{~s}$ & 14.5 & 20.4 \\
\hline $\mathrm{OCH}_{3}$ & 51.4 & $3.50 \mathrm{~s}$ & 51.4 & 50.8 \\
\hline
\end{tabular}

Dry seed pods $(2.5 \mathrm{~kg})$ were powdered and extracted with $n$-hexane (6L) for 5 days at room temperature. After filtration and evaporation of solvent at reduced pressure a crude extract (110 g) was obtained as an oily resin. A sample of resin $(5 \mathrm{~g})$ was submitted to acid and base extraction to furnish acidic fraction $(3.3 \mathrm{~g})$. Treatment with excess diazomethane gave esterified extract ( $3.4 \mathrm{~g})$ which was submitted to successive purification by silica gel column chromatography (petroleum ether : EtOAc, 95:5, v/v) to yield (-)-methyl zanzibarate (6) as colorless crystals $\left\{150 \mathrm{mg}, \mathrm{mp} 132-134^{\circ} \mathrm{C},[\alpha]_{\mathrm{D}}^{20}-37.5 \mathrm{CHCl}_{3}, c\right.$ 2.0; lit., ${ }^{8}$ $\left.[\alpha]_{\mathrm{D}}-37.0, \mathrm{CHCl}_{3}, c 1.0\right\}$. GC/MS analysis of the esterified extract indicated the presence of methyl isoozate (4) (5.7\%), methyl ozate (5) $(46.5 \%)$ and methyl kovalenate (6) $(10.5 \%)$.

\section{Methyl (-)-(5R,8S,9S,10R)-clerod-3-en-15-oate (3)}

Viscous oil, $[\alpha]_{\mathrm{D}}^{20}-54.0\left(\mathrm{CHCl}_{3}, \mathrm{c} 0.6\right)$; HREIMS $m / z$ : $320.27156[\mathrm{M}]^{+}$(calcd 320.27153 for $\mathrm{C}_{21} \mathrm{H}_{34} \mathrm{O}_{2}$ ); IR $v_{\max } / \mathrm{cm}^{-1}: 1741,1458,1436,1381,1162,1096,1012$ (film); ${ }^{1} \mathrm{H}$ NMR see Table $1 ;{ }^{13} \mathrm{C}$ NMR see Table 1.

\section{Acknowledgements}

This work was performed with financial support of FAPESP. RTN thanks CAPES and FAEP/UNICAMP for fellowships and RAG acknowledges FAPESP. We also thank Dr. L.H.B. Baptistella and Dr. C.H. Collins for helpful discussion and suggestions.

\section{References}

1. Corrêa, M.P.; Dicionário de Plantas Úteis do Brasil, Ministério da Agricultura, IBDF, Imprensa Nacional: Rio de Janeiro, 1984, p. 593.

2. Neves, M.C.A.; Neves, P.C.A.; Zanini, J.C.; Medeiros, Y.S.; Yunes, R.A.; Calixto, J.B.; Phytother. Res. 1993, 7, 356.

3. Bisby, F.A.; Buckingham, J.; Harborne, J.B.; Phytochemical Dictionary of the Leguminosae. Plants and their Constituents, Chapman \& Hall: London, 1994, Vol. 1, p. 357.

4. Nogueira, R.T.; Shepherd, G.J.; Laverde Jr., A.; Marsaioli, A.J.; Imamura, P.M.; Phytochemistry 2001, 58, 1153.

5. Lee, Y.T.; Langenheim, J.H.; Systematics of the genus Hymenaea L., Chemistry of California Press Ltd.: Los Angeles, 1975, Vol. 69.

6. Nunes, F.M.N.; Imamura, P.M.; J. Braz. Chem. Soc. 1996, 7, 181.

7. Bevan, C.W.L.; Ekong, D.E.U.; Okogum, J.I.; J. Chem. Soc. C, 1968, 1067.

8. Hugel, G.; Ourisson, G.; Bull. Soc. Chim. Fr. 1965, 2903.

Received: August 31, 2001 Published on the web: April 15, 2002

FAPESP helped in meeting the publication costs of this article. 